\title{
Empowering Program as a Special Service for the Poor Parents of Children with Special Needs (CSN)
}

\author{
${ }^{1}$ SR Hadiati, ${ }^{2}$ SD Kirana, ${ }^{3}$ T Maknun, ${ }^{4}$ NI Rosyadah, ${ }^{5} \mathrm{HW}$ Puspitasari \\ ${ }^{6 *}$ A Meilinawati, ${ }^{7}$ RNRP Gofur
}

1, 2, 3, 4, 5, 6,7 Yayasan Peduli Kasih Anak Berkebutuhan Khusus, Surabaya, Indonesia

\begin{abstract}
Children with special needs (CSN) are individuals who are under 18 years or older whose mental condition is under 18 years and have growth and development problems that require special services, the Government has provided several facilities for CSN as a form of empowerment. However, these services have not yet led to the empowerment of CSN through education on public awareness to understand the needs and potential of CSN. Therefore, an empowerment program through parents is needed as a significant other of CSN. The purpose of this study is to find out the picture if the CSN parent empowerment program is carried out. The method used is through a qualitative approach and action research. The results showed that the CSN parent empowerment program needs to collaborate with various parties by growing trust in CSN parents to maintain commitment in participating in the program.
\end{abstract}

Keywords: Children with special needs (CSN), CSN parents, empowering

\section{Research Background}

Indonesia is the fourth most populous country in the world based on data from Worldometers (2019). One of the population of Indonesia's population is dominated by the population of children who are in the age range of 0-14 years (Bappenas in databoks.katadata.co.id., 2019). This population plays an important role as the next generation of the nation. Like humans, not all children have perfection. There are some children who have problems with growth and development. These children are called special needs children (CSN). The definition of CSN has so many meanings that the researchers conclude that CSN is an individual under the age of 18 or above but who has a mental age under 18 who has growth and development problems that requires special services.

Based on SUPAS data (2015), there are 2 million CSN in Indonesia. This has come to the

\footnotetext{
* Corresponding author: Ardiana Meiliawati ardmeilinawati@gmail.com

Published online at http://IJDS.ub.ac.id/

Copyright (C) 2019PSLD UB Publishing. All Rights Reserved
}

attention of the government to provide special services to CSN for the realization of people's welfare. Such services can be in the form of special facilities in public places such as the provision of elevators at the Crossing People Bridge (Lathifiyah, 2019), inclusive education (Kemendikbud, 2019), and the Indonesia Sehat Card program as a form of health insurance for persons with disabilities (Maharani, 2015).

International law also supports the fulfillment of rights for CSN through the Convention on Disability Rights in force since 2008 (Wikipedia, 2019). There are 20 ratifications, one of which was done by Indonesia through RI Law No. 19 of 2011 concerning Ratification of the Convention on the Rights of Persons with Disabilities (BPHN, 2019). The government also established 16 laws and regulations to fulfill the rights of persons with disabilities such as Law no. 20 of 2003 concerning the National Education System, Law No. 36 of 2009 concerning Health, and Law No. 25 of 2009 concerning Public Services.

However, these services have not been optimally optimized by both the government and the community (Rachmaningtyas, 2013; Cahyu, 
2017, Safitri, 2019). The data states that only $36.4 \%$ of CSN have received education (SUPAS, 2015). In addition, the economic limitations of CSN's parents resulted in a lack of understanding of CSN. Most CSN parents do not yet understand the needs, abilities, and potential of their children (Rafikayati \& Jauhari, 2018). Ignorance of parents in accessing services and information is also an obstacle in understanding CSN (Pro Balikpapan, 2015).

Environmental factors also affect the lives of CSN. Surrounding communities tend not to understand and accept CSN conditions in their environment (Putra, 2016; Kemenpppa, 2018). This is influenced by cultural factors, for example karma (Riany et al. In Suwartono \& Widyawati, 2018). Stigma also affects the CSN condition in living their daily lives. Kusumastuti, et al. also mentioned that this factor could limit families to find and access professional services in supporting the growth and development of CSN (Suwartono \& Widyawati, 2018). Similarly, CSN parents who have to face the shame of the special conditions that their children have. In overcoming this problem, we need a service that provides education for CSN parents and the surrounding environment. This service is an empowerment program through education to increase the awareness of CSN parents and the community in order to create a CSN-friendly environment. This is intended to encourage CSN acceptance in the community so that the realization of inclusive communities.

Surabaya as one of the cities that received the Child Worthy City award in 2018 (Tempo, 2018) became a region that has the potential to create a friendly city for children with special needs. As a result, many inclusive education has developed in Surabaya. However, educational services for CSN parents and the community are still small so there is a need for efforts from other parties to create a CSN-friendly environment (Republika, 2014). One such party is the Children's Love Care Foundation for Special Needs (YPKCSN) which carries out a special empowerment program for parents of children with special needs.

YPKCSN focuses on CSN parents who are believed to have the ability to help themselves and their children. One of the efforts made to achieve this goal is through an empowerment program conducted by YPKCSN. The programs use a parent support group approach (Urosevich, 2013) where the activities carried out include informal discussions, home visits, and simple training. Although the empowerment program has been held since 2012, there are still many obstacles that are experienced. Trust, mindset, and language limitations are the main obstacles in realizing goals (Flores, 2006). There are still parents who have not committed to take part in this program.

Departing from the existing problems, this study was conducted to provide an overview of the empowerment program conducted by YPKCSN. The results of this study are expected to be used as a reference and learning to provide services in the form of CSN parent empowerment programs. This service is carried out free of charge. Parents will participate in activities such as discussions to share with other parents in handling CSN. During the activity, CSN will take an art or music class accompanied by volunteers. This service also provides scholarships for CSN development if CSN parents commit to take part in an empowerment program.

\section{Method}

\subsection{Design and settings}

This study uses a qualitative approach and action research. The qualitative approach was chosen because not all CSN parents can be open with their conditions so that they need an approach that creates trust. Action research was chosen because this research was carried out at the time the activity took place namely when the YPKCSN empowerment program was implemented. In addition, this research is intended to make improvements to further foundation programs. Moreover, this research is expected to be able to propose the government to provide special services for CSN. This research was carried out in Mulyorejo District, Surabaya as a CSN-friendly sub-district. In addition, the location of foundations included in this area is another consideration to facilitate the assistance process.

Cite this as:

Hadiati, SR et al. Empowering Program as a Special Service for the Poor Parents of Children with Special Needs (CSN). Indonesian Journal of Disability Studies (IJDS).2019: Vol. 6(2): PP 223-229. 


\subsection{Study procedures}

Before conducting research, researchers work together with various parties. Some of them are collaboration with the Faculty of Psychology at Sunan Ampel State Islamic University in Surabaya, the Faculty of Psychology at the University of Surabaya, and the Faculty of Psychology at the 17 August 1945 University in Surabaya to send students.

Participants included in this study were local officials, local leaders, and special needs families. There are several stages carried out in this study, namely:

1. Preliminary studies. Researchers a number of 4 foundation staff conducted focus group discussions (FGD) for 2 days. After that, researchers conducted 17 indepth interviews with CSN families who were members of the foundation. From seventeen data, there are 7 CSN parents who showed their commitment to join the empowerment program. In addition, the seven special needs parents received a scholarship that was used to optimize the potential of special needs.

2. Volunteer training and mentoring. The volunteers consisted of 15 students majoring in psychology to attend the training. The training provides information on how to control CSN at home, building trust and bonding with CSN parents. Assistance is carried out for 3 months. The result was that there were 7 research assistants who took part in the training in the form of CSN understanding and problems, the role of volunteers, and the practice of being CSN facilitators. These seven people act as friends of CSN's parents, not CSN examiners.

3. Assessment of the conditions of CSN and parents. This stage is carried out by 2 psychologists and 1 doctor to assess the commitment of parents to participate in an empowerment program. In addition, CSN's parents together with researchers compiled an Individual Learning Program (PPI) for each CSN.

4. Assistance and data reporting. Visiting CSN's home is an activity carried out every week to observe and interview CSN families regarding their condition. The data is also used as a reference for developing the Individual Learning Program for each CSN.

5. Data analysis. After all data is collected, data analysis is performed to find the criteria obtained in it.

\subsection{Analysis}

The analysis technique used is thematic analysis. Researchers provide information and find findings. All observations and interviews are transcribed and identified to find suitable findings. Categorization of findings is done by analyzing the transcript repeatedly. Triangulation was carried out between the three informants namely local officials, local leaders, and families of special needs.

\subsection{Results}

There are three participants consisting of local officials, local leaders, and families of special needs. Local officials include the local head, head of the health center, local health staff, educators and local coordinators. Local leaders in the form of religious leaders and heads of RT and RW. Then, the CSN family consists of members such as fathers, mothers, siblings, grandparents, and other parties who live with CSN. Observations and interviews were conducted with participants regarding their views on the YPKCSN empowerment program. The findings are as follows.

\subsubsection{Demographic data}

Data by sex is divided into males and females. There were 8 men and 18 women as local officials, 12 men and 36 women as local leaders, and 12 men and 17 women from members of the CSN family in the local area. Data based on gender can be seen in table 1 .

Table 1. Demographic data based on criteria of sex

\begin{tabular}{|c|l|c|c|}
\hline No & \multicolumn{1}{|c|}{ Types of Informan } & Men & Women \\
\hline 1 & Formal leaders & 8 & 18 \\
\hline 2 & Informal leaders & 12 & 36 \\
\hline 3 & $\begin{array}{l}\text { Member of family of } \\
\text { poor CSN }\end{array}$ & 12 & 17 \\
\hline
\end{tabular}


Based on age, the data is divided into participants who are classified as younger (age under 40 years), medium (age 40-55 years), and older (age over 55 years). There are 6 people with a younger age, 14 people with a middle age, and 6 people with an older age as local officials. There are 8 people with a younger age, 18 people with a middle age, and 22 people with an older age as local figures. In addition, there are 4 people with a younger age, 20 people with a middle age, and 5 people with an older age than members of the CSN family. Data based on age can be seen in table 2 .

Table 2. Demographic data based on age

\begin{tabular}{|c|l|c|c|c|}
\hline No & $\begin{array}{c}\text { Types of } \\
\text { Informan }\end{array}$ & $\begin{array}{c}\text { Younger } \\
\text { (under } \\
\mathbf{4 0} \mathbf{y . 0})\end{array}$ & $\begin{array}{c}\text { Middle } \\
\mathbf{4 0 - 5 5} \\
\mathbf{y . 0})\end{array}$ & $\begin{array}{c}\text { Older } \\
\mathbf{5 5} \mathbf{y . 0} \\
\text { and } \\
\text { above) }\end{array}$ \\
\hline 1 & $\begin{array}{l}\text { Formal } \\
\text { leaders }\end{array}$ & 6 & 14 & 6 \\
\hline 2 & $\begin{array}{l}\text { Informal } \\
\text { leaders }\end{array}$ & 8 & 18 & 22 \\
\hline 3 & $\begin{array}{l}\text { Member } \\
\text { of family } \\
\text { of poor } \\
\text { CSN }\end{array}$ & 4 & 20 & 5 \\
\hline
\end{tabular}

Based on the level of education, the data is divided into participants with primary, secondary and undergraduate education or above. There are 4 people with secondary education and 22 scholars and above as local officials. There are 12 people with basic education, 26 with secondary education, and 8 scholars and above as local figures. Then, there are 6 people with basic education, 18 with secondary education, and 5 graduates and above as members of the CSN family. Data based on education level can be seen in table 3 .
Table 3. Demographic data based on education level

\begin{tabular}{|l|l|c|c|c|}
\hline No & $\begin{array}{l}\text { Types of } \\
\text { Informan }\end{array}$ & $\begin{array}{l}\text { Graduation } \\
\text { of basic } \\
\text { level }\end{array}$ & $\begin{array}{l}\text { Graduation } \\
\text { of middle } \\
\text { level }\end{array}$ & $\begin{array}{l}\text { Bachelor } \\
\text { and } \\
\text { beyond }\end{array}$ \\
\hline 1 & $\begin{array}{l}\text { Formal } \\
\text { leader }\end{array}$ & 0 & 4 & 22 \\
\hline 2 & $\begin{array}{l}\text { Informal } \\
\text { leader }\end{array}$ & 12 & 26 & 8 \\
\hline 3 & $\begin{array}{l}\text { Member } \\
\text { of family } \\
\text { of poor } \\
\text { CSN }\end{array}$ & 6 & 18 & 5 \\
\hline
\end{tabular}

\subsubsection{Findings}

The results of observations and interviews conducted refer to three things that illustrate that the empowerment program needs to be carried out using a holistic or holistic approach. These findings are:

1. Involving the opinions of local officials and figures as structural aspects to adapt to local culture and values that grow in the community. This can be done through informal discussions and ongoing relationships. The empowerment program must adapt to the context in which the program is implemented. In this case, local officials and leaders are very important because they have gained the trust of the local community.

2. Collaboration with various parties such as lecturers, practitioners, religious leaders, and volunteers. The success of the development program is also determined by the best performance given by various parties. The target can be achieved if the parties also have the same mindset as the empowerment program implemented. In addition, a trusting relationship also needs to be maintained.

3. Assistance and communication with all aspects. The consistency and continuity of the sea empowerment program is carried out with ongoing assistance and communication processes. The number of parties invited to cooperation would certainly be a barrier. However, as long as communication is always established, these parties become the most important 
part in implementing the empowerment program.

The CSN parent empowerment program conducted by YPKCSN is a program that is free of fees. Therefore, support from all parties, especially local officials are important to support the empowerment of CSN parents. In addition, a sincere relationship with all parties is an important key in maintaining the consistency and continuity of the CSN parent empowerment program. These are the two factors supporting the realization of optimal CSN parental empowerment.

However, the CSN parent empowerment program also certainly has challenges during its implementation. Based on observations and interviews conducted, most of the problems experienced are communication limitations. This is caused by the mindset of parents who are inferior, feel unable and unable to care for their children. In addition, the low commitment of parents becomes an obstacle to the implementation of the CSN parent empowerment program. This level of commitment is also influenced by the environment that has not been able to accept the CSN conditions in their area of residence.

\subsection{Discussion}

Based on these findings, the empowerment of CSN parents seems not easy to do. There are still many challenges that need to be faced during the program implementation. From demographic data, it was found that the majority of participants were people with secondary education. Some of them may not understand the fulfillment of needs and optimization of the CSN. In addition, the majority of participants are in the middle age of 40-55 years. This age is classified as an active age so that their time will be used more to make ends meet. From this data, there is a need for services in the form of education to raise awareness of the condition of CSN. In accordance with the statement of BlumenthalBarby (2007), the personal characteristics and background of parents influence the activeness of parents to empower their children.

The findings that have been described indicate the need for close relations with the parties invited to work together to implement the CSN parent empowerment program. With appropriate relationships, parents will be more motivated to do better business and apply their knowledge in caring for CSN. The potentials of CSN will reach their best if there is a close parent relationship (Hibbard \& Greene, 2013). Closeness of the relationship also shows continuity in caring for and understanding CSN conditions in depth.

From the environmental side, it is necessary to have facilities that support knowledge about CSN. This has an impact on the level of community awareness to accept CSN as part of their environment. Public confusion in supporting, behaving, or interacting with CSN is an illustration of the creation of a CSN-friendly environment. So from this, we need an educational facility or service for the community regarding CSN.

Educational facilities provided should be able to change the mindset of the community towards parents who have children with special needs. This can be in the form of psychoeducation regarding children with special needs and caregiving. The psychoeducation provided can also be in the form of preventive measures in preventing disability in the baby to be born. The baby's condition is also influenced by the health of the womb, one of which can lead to the emergence of special needs.

\subsection{Limitations}

This research is also not free from deficiencies. Some of them are the implementation of programs that are only focused on one particular district. This has not yet been able to explain the implementation of the empowerment program elsewhere. The values of local residents certainly influence the implementation of the program so that the output produced in Mulyorejo District may be different from that of other districts in Surabaya.

\subsection{Conclusion}

The CSN parent empowerment program at no charge is carried out in collaboration with various parties such as local officials, local leaders, and members of the CSN family. The success of an empowerment program is determined by the quality of the relationship being fostered and the commitment of parents. The findings of this study are expected to provide a reference to support better educational facilities regarding the needs and optimization of the potential of CSN. 


\section{Bibliography}

Antara (2018), "Surabaya Raih Penghargaan Kota Layak Anak, Risma: Alhamdulillah...", https://nasional.tempo.co/read/1109949, accessed at Saturday, September $9^{\text {th }} 2019,10.42$ WIB.

Blumenthal-Barby, J, 2017. Seeking better health care outcomes. The American Journal of Bioethics, 12 (2), pp.1-10

BPHN (2011), "UU No. 19 Tahun 2011", https://www.bphn.go.id/data/documents/11uu01 9.pdf, accessed at Saturday, September $9^{\text {th }} 2019$, 10.33 WIB.

Cahyu (2017), "Penyandang Disabilitas Masih Belum Sejahtera. Apa Solusinya?", https://www.liputan6.com/news/read/318897, accessed at Saturday, September $9^{\text {th }} 2019,10.34$ WIB.

Carman KI, 2013. Parents and family engagement : a framework for understanding the elements and developing interventions and policies. Health Affair, 32 (2), pp. 223-231

Databoks (2019), “Jumlah Penduduk Indonesia Menurut Kelompok Umur dan Jenis Kelamin (2019)",

https://databoks.katadata.co.id/datapublish, accessed at Saturday, September $9^{\text {th }} 2019,10.27$ WIB.

Flores, G, 2006. Language barriers to health care in the developing countries. The New England Journal of Medicine, 353 (3), pp.229-231

Guadagnoli, E and Ward P, 1998. Parent participation in decision making. Social Science and Medicine, 47 (3), pp. 329-339.

Hibbard J and Greene J, 2013. What the evidence shows abotu parent activation: better health outcomes and care experiences; fewer data on costs. Health Affairs, 32 (3), pp. 207-214.

International Labour Organisation, 2011. Inclusion of People with Disabilities in Indonesia.

Kemendikbud (2019), “Kemendikbud Ajak Daerah Tingkatkan Pendidikan Inklusif", https://www.kemdikbud.go.id/main/blog/2019, accessed at Saturday, September $9^{\text {th }} 2019,10.29$ WIB.

Kemenpppa (2018), "Membangun Masa Depan Anak Berkebutuhan Khusus", https://www.kemenpppa.go.id/index.php, accessed at Saturday, September $9^{\text {th }} 2019,10.40$ WIB.

Lathifiyah, K. (2019), "Pemkot Surabaya Tambah Fasilitas Publik untuk Penyandang Disabilitas", https://jatimnet.com/pemkotsurabaya, accessed at Saturday, September $9^{\text {th }}$ 2019, 10.28 WIB.

Macionis, J.J, 2008. Sociology. New Jersey: Pearson Prentice Hall

Maharani, E. (2015), "24 Ribu Penyandang Disabilitas Daftar Dapatkan KIS dan KIP", https://www.republika.co.id/berita/nasional, accessed at Saturday, September $9^{\text {th }} 2019,10.30$ WIB.

Prokal (2015), "SLBN PPU Kekurangan Sarana dan Prasarana", https://balikpapan.prokal.co/read/news/17864, accessed at Saturday, September $9^{\text {th }} 2019,10.38$ WIB.

Putra, R. I. P. A. \& Ardianingsih, F. (2016), "Survey Opini Masyarakat Tentang Anak Berkebutuhan Khusus di Kelurahan Medokan Semampir Kecamatan Sukolilo Kota Surabaya”, Jurnal Pendidikan Khusus, page 2-11, Surabaya.

Rachmaningtyas, A. (2013), "Pelayanan kepada lansia \& disabilitas belum maksimal", https://nasional.sindonews.com/read/784023, accessed at Saturday, September $9^{\text {th }} 2019,10.34$ WIB.

Rafikayati, A. \& Jauhari, M. N. (2018), "Keterlibatan Orangtua dalam Penanganan Anak Berkebutuhan Khusus", Jurnal Abadimas Adi Buana, Vol. 02, No. 1, page 55-64, Surabaya.

Republika (2014), "Hak Anak Difabel", https://www.republika.co.id/berita/koran, accessed at Saturday, September $9^{\text {th }} 2019,10.44$ WIB.

Cite this as:

Hadiati, SR et al. Empowering Program as a Special Service for the Poor Parents of Children with Special Needs (CSN). Indonesian Journal of Disability Studies (IJDS).2019: Vol. 6(2): PP 223-229. 
Safitri, E. (2019), "ICW Soroti Minimnya Layanan Kesehatan bagi Penyandang Disabilitas", https://news.detik.com/berita/4671739, accessed at Saturday, September $9^{\text {th }} 2019,10.35$ WIB.

SUPAS, 2015. Profil Penduduk Indonesia, Jakarta : Badan Pusat Statistik

Susanto, Elik (2018), Surabaya Raih Penghargaan Kota Layak Anak, Risma: Alhamdulillah.., https://nasional.tempo.co/read/1109949/, accesed at Saturday, $9^{\text {th }}$ September 2019, 12.37 WIB

Suwartono, C. \& Widyawati, Y. (2018), "Pengembangan Skala Resiliensi Keluarga dengan Anak Berkebutuhan Khusus", Jurnal Humanitas, Vol. 15, No. 2, page 82-95, Jakarta.
United Nations, 2008. Convention on the rights of Person with Disabilities.

Urosevich, K. (2013), "It Takes a Hui to Raise a Child: A Case for Peer-to-Peer Support for Child Abuse Prevention", Hawaii Journal Med Public Health, Vol. 72, No. 10, page 365-368, Hawaii.

Wikipedia (2019), "Konvensi mengenai Hak-hak Penyandang Disabilitas", https://id.wikipedia.org/wiki/Konvensi, accessed at Saturday, September $9^{\text {th }} 2019,10.31$ WIB.

Worldometers (2019), "Indonesian Population", https://www.worldometers.info/world-, accessed at Saturday, September $9^{\text {th }} 2019,10.25$ WIB.

World Health Organisation, 2011. Introductory Booklet on Community Based Rehabilitation. 